\title{
Bengt Robertson (1935-2008): A Pioneer and Leader in Surfactant Research
}

The world of neonatology and in particular surfactant research will be a different place in 2009 following the death of Professor Bengt Robertson in Stockholm on Sunday 7th December 2008. He suffered his final illness with great dignity and fortitude, and news of his death was met with great sadness by his many friends and colleagues worldwide. As an example, Colin Morley from Melbourne commented 'Bengt has been one of my research heroes since I was a fellow in the 1970 s when I read his seminal papers about surfactant in rabbit pups. The extraordinary thing about Bengt is that he continued to do very relevant and high quality research on surfactant all his life. He was the primary leader in surfactant research all his working life continuing to produce innovative and significant findings right up to the end'.

Bengt A. Robertson was born on 14th September 1935 in Stockholm just 6 years after Kurt van Neergaard, another Swede, first recognised the importance of pulmonary surfactant for normal lung function [1] (vide infra). Bengt Robertson passed his high school diploma at Södra Latins Gymnasium in Stockholm in 1953 and then studied medicine at the Karolinska Institutet in Stockholm graduating MD in 1960. In 1968 he was awarded a PhD after publication of his thesis entitled 'The intrapulmonary arterial pattern in normal infancy and in transposition of the great arteries'. In 1970 he was appointed as a Consultant in Pediatric Pathology at St Göran's Hospital in Stockholm. From 1974 to 2000 he was Director of the Division for Experimental Perinatal Pathology in the Department of Women and Child Health at the Karolinska Institutet. In 2000, Bengt Robertson was appointed as Adjunct Professor of Perinatal Pathology, a post which

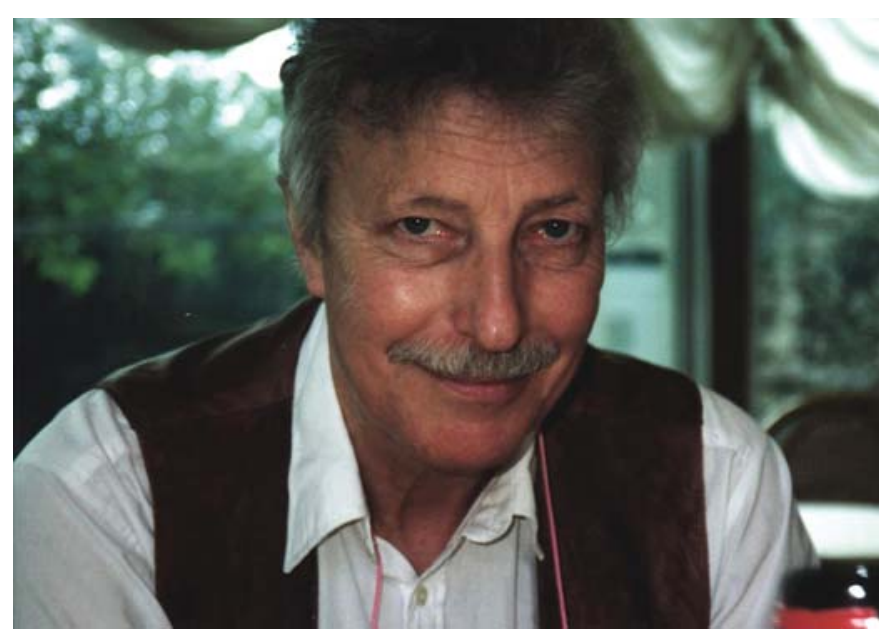

Bengt Robertson (1935-2008).

recognised his research contributions and his Directorship of the Division of Pediatric Pathology at the Karolinska Hospital from 1994 to 1997. During his time in Stockholm, Bengt was appointed a visiting professor on two occasions: in 1976 at the University of Toronto in Canada and in both 1985 and 1987 at the University of Perugia in Italy. Bengt Robertson's research interests focussed on the surfactant system of the lung and it was his collaboration with Goran Enhorning, an Obstetrician in Stockholm, that was to prove to be fundamentally important.

Soon after Avery and Mead showed in 1959 that respiratory distress syndrome (RDS) was due to primary sur-

\section{KARGER}

Fax +4161306 1234 E-Mail karger@karger.ch www.karger.com
(C) 2009 S. Karger AG, Basel

1661-7800/09/0952-00VI\$26.00/0 
factant deficiency [2], two trials of nebulised synthetic surfactant, composed of dipalmitoylphosphatidylcholine (DPPC), showed negative results in the treatment of RDS $[3,4]$. In the early 1970s it was Bengt Robertson and Goran Enhorning who discovered the reasons for the failure of nebulised synthetic surfactant when they reported that natural surfactant instilled into the tracheas of immature rabbits was an effective treatment for RDS $[5,6]$. For surfactant to be an effective treatment, a natural preparation containing surfactant proteins needs to be instilled directly into the lungs of preterm infants. This was the major breakthrough in surfactant research that led to many later clinical trials with natural surfactant preparations. At the same time, Bengt worked with a young Paediatric Surgeon, Gertie Grossmann, who was later to become his partner and mother to their four younger daughters. Bengt also had four children from his first marriage: one daughter and three sons who were born between 1956 and 1962 when Bengt was studying at the Karolinska Institutet.

Following these early studies with natural surfactant in immature rabbits, Bengt Robertson, together with Tore Curstedt from the Department of Clinical Chemistry at the Karolinska Institutet, developed a porcine surfactant that they later called Curosurf, a name derived from the first two letters of their surnames [7]. After animal testing, Curosurf was studied in a randomised controlled trial to treat preterm babies suffering from severe RDS [8]. This trial was conducted by the Collaborative European Multicenter Study Group, a collection of neonatologists and basic scientists from many countries in Europe, brought together by Bengt Robertson. Curosurf was shown to reduce pulmonary air leaks and neonatal mortality in preterm infants with severe RDS [8] and later studies helped to define dosing regimens $[9,10]$, the optimal timing of treatment [11-13] and the role of surfactant combined with CPAP $[14,15]$. Bengt Robertson was the driving force behind these impressive clinical trials and their importance was in helping to determine the optimal regimens for surfactant treatment in the preterm infant [16]. Undoubtedly, the work of Bengt Robertson led to the saving of many thousands of lives of premature babies worldwide and in 1996 he was awarded the King Faisal International Prize for Medicine jointly with Tetsuro Fujiwara from Japan for their studies with surfactant leading to improved survival of the premature infant.

Bengt Robertson received many other awards and honours during his lifetime recognising his prodigious research in the field of surfactant replacement therapy.

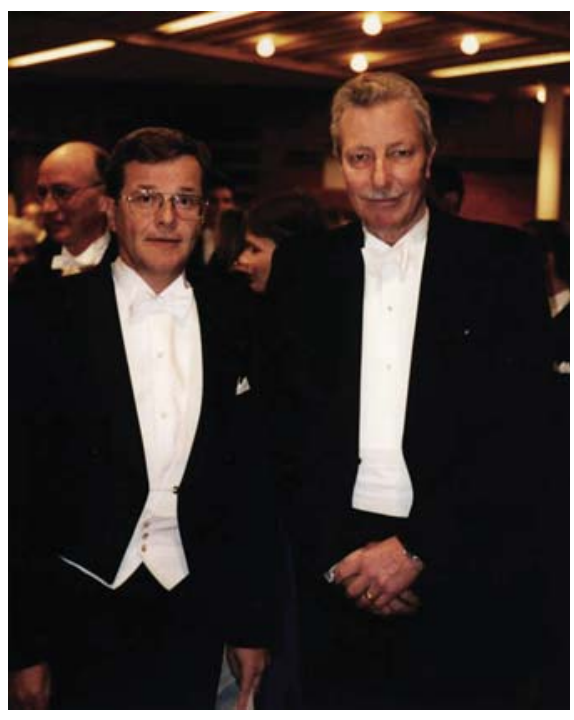

Tore Curstedt and Bengt Robertson on receiving the Hilda and Alfred Eriksson's Prize from the King of Sweden in 1998.

These included: Honorary Membership of the Italian Society of Perinatal Medicine in 1987, Fellowship of the Royal College of Physicians of Edinburgh in 1996, the Hilda and Alfred Eriksson's Prize awarded by the Royal Swedish Academy of Sciences in 1998, the Maternité Prize of the European Association of Perinatal Medicine in 2002 and the Lars Werko Prize awarded by the Heart Lung Foundation jointly with Tore Curstedt in 2004. His research output was phenomenal with 5 textbooks and over 700 publications comprising about 270 original papers and about 150 review articles in addition to numerous abstracts and letters. However, many are probably unaware that he also published books of short stories and poetry earlier in his career: Nachspiel in 1967, Nefertites Öga in 1970 and Naturens Gong in 1975. While visiting Japan to undertake collaborative surfactant research, Bengt became interested in Haiku poetry and on returning to Stockholm started to write Haiku becoming an active member of the Swedish Haiku Association and winning competitions for his poems. Besides his creative writing and poetic talents, Bengt Robertson was a multilingual communicator and a gifted musician who played the piano, flute, trumpet and bass tuba in the Jubilee Jazz Band, specialising in Dixieland music. In addition, he loved classical music, fine arts and intellectual creativity and challenges of many kinds.

As Colin Morley stated, Bengt Robertson continued to be very productive throughout his life and was regarded 
by his many postgraduate students as an excellent teacher and mentor. From 1974 he supervised a number of doctoral students, all of whom became distinguished academic professors in many parts of the world. We, as authors of this obituary, have good reason to be especially thankful for having met Bengt Robertson at very important times in our lives and we certainly owe him a lot. With his open, warm and charming personality as well as his unpretentious character and his brilliant mind, he stimulated and inspired us in many ways and helped us develop important research collaborations and projects.
But more than this, he was a true friend and colleague; we will miss him dearly. The world of surfactant research and neonatology in general will be a poorer place in 2009 with the passing of Bengt Robertson. However, the legacy that he has left will remain to stimulate other younger clinicians and researchers who will carry forward his ideas to benefit premature babies worldwide. We send our condolences to his wider family circle.

\section{Henry L. Halliday, Belfast \\ Christian P. Speer, Würzburg}

\section{References}

1 Von Neergaard K: Neue Auffassungen über einen Grundbegriff der Atemmechanik. Die Retraktionskraft der Lunge, abhängig von der Oberflächenspannung in den Alveolen. Z Gesamte Exp Med 1929;66:373-394.

$\checkmark 2$ Avery ME, Mead J: Surface properties in relation to atelectasis and hyaline membrane disease. Am J Dis Child 1959;97:517-523.

3 Robillard E, Alarie Y, Dagenais-Perusse P, Baril E, Guilbeault A: Microaerosol administration of synthetic $\beta-\gamma$-diplamitoyl-L- $\alpha$ lecithin in the respiratory distress syndrome: a preliminary report. Can Med Assoc J 1964; 90:55-57.

4 Chu J, Clements JA, Cotton EK, Klaus MH, Sweet AY, Tooley WH: Neonatal pulmonary ischemia. 1. Clinical and physiological studies. Pediatrics 1967;40:709-782.

5 Enhorning G, Robertson B: Lung expansion in the premature rabbit fetus after tracheal deposition of surfactant. Pediatrics 1972;50: 709-782.

-6 Enhorning G, Grossmann G, Robertson B: Tracheal deposition of surfactant before the first breath. Am Rev Respir Dis 1973;107: 921-927.

7 Halliday HL, Speer CP: Bengt Robertson: a surfactant pioneer. Biol Neonate 2002;82: 272-273.
8 Collaborative European Multicenter Study Group: Surfactant replacement therapy for severe neonatal respiratory distress syndrome: an international randomized clinical trial. Pediatrics 1988;82:683-691.

-9 Speer CP, Robertson B, Curstedt T, Halliday HL, Compagnone D, Gefeller O, Harms K, Herting E, McClure G, Reid M, Tubman R, Herin P, Noack G, Kok J, van Sonderen L, Laufkotter E, Kohler W, Boenisch H, Albrecht K, Hannsler L, Haim M, Oetomo SB, Okken A, Altfeld PC, Groneck P, Kachel W, Relier JP, Walti H: Randomized European multicenter trial of surfactant replacement therapy for severe neonatal respiratory distress syndrome: single versus multiple doses of Curosurf. Pediatrics 1992;89:13-20.

10 Halliday HL, Tarnow-Mordi WO, Corcoran JD, Patterson CC: Multicentre randomised trial comparing high and low dose surfactant regimens for the treatment of respiratory distress syndrome (the Curosurf 4 trial). Arch Dis Child 1993;69:276-280.

11 Egberts J, de Winter JP, Sedin G, de Kleine MJ, Broberger U, van Bel F, Curstedt T, Robertson B: Comparison of prophylaxis and rescue treatment with Curosurf in neonates less than 30 weeks' gestation: a randomized trial. Pediatrics 1993;92:768-774.
12 Walti H, Paris-Llado J, Breart G, Couchard $\mathrm{M}$ : Porcine surfactant replacement therapy in newborns of 25-31 weeks' gestation: a randomized, multicentre trial of prophylaxis versus rescue with multiple low doses. The French Collaborative Multicentre Study Group. Acta Paediatr 1995;84:913-921.

13 Bevilacqua G, Parmigiani S, Robertson B: Prophylaxis of respiratory distress syndrome by treatment with modified porcine surfactant at birth: a multicentre prospective randomized trial. J Perinat Med 1996;24:609620.

14 Verder H, Robertson B, Greisen G, Ebbesen F, Albertsen P, Lundstrom K, Jacobsen T: Surfactant therapy and nasal continuous positive airway pressure for newborns with respiratory distress syndrome. DanishSwedish Multicenter Study Group. N Engl J Med 1994;331:1051-1055.

15 Verder H, Albertsen P, Ebbesen F, Greisen G, Robertson B, Bertelsen A, Agertoft L, Djernes B, Nathan E, Reinholdt J: Nasal continuous positive airway pressure and early surfactant therapy for respiratory distress syndrome in newborns of less than 30 weeks' gestation. Pediatrics 1999;103:e24.

16 Robertson B, Halliday HL: Principles of surfactant replacement. Biochim Biophys Acta 1998;1408:346-361. 